\title{
THE ROLE OF FRUIT PRODUCTION IN EVERYDAY LIFE IN BÜKKALJA IN THE 19-20TH CENTURY
}

\author{
Zoltán Borbély
}

\begin{abstract}
Fruit-growing played a very varied role in the folk culture of the settlements of Bükkalja. Fruit was one of the most important commodities in the trade between the Great Plain and the Highlands; nevertheless its production was based on extremely low quality cultivation. In spite of the fact that it was only a supplement to the livelihoods of the local population, it played an extremely important role. However, intensive horticulture was not developed in the area.
\end{abstract}

Keywords: agricultural history, Bükkalja, fruit production, agricultural statistics CODE: B19 


\section{Introduction}

Bükkalja, geographically, a group of small-landscapes, consists of the region south of the border of Southern-Bükk, between the valleys of the rivers Tarna and Sajó, running southwards to Heves Plain and Borsodi-Mezőség, dissected by mountain ridges. This area carries, both in terms of wildlife and folk culture, the characteristics of the transitional landscapes that have been developed by the traditional division of labour and product exchange between the Great Plain and the Highlands over the centuries. This so-called trade line, which runs through the transitional areas of the Carpathian Basin, has shaped the way of life and farming of the people living there in each region in different ways. (Frisnyák, 1995)

However, Bükkalja as a natural geographic region does not form an independent region in terms of Hungarian folk culture. From the north it comes into contact with Palócföld and Barkóság, and from the south the folk and agricultural culture of the area was influenced by the ethnographic landscape of "Borsod-Heves Tisza mente" (the Shoreline of the River Tisza in Borsod and Heves Counties)." (Baráz, 2014) In my study, I analyse a single element of the myriad factors forming the intense social and economic relationships resulting from unique landscape cultivation and dynamic land use, the role of fruit production and fruit trade at the turn of the 19th-20th centuries.

\section{Sources}

The aim of the basic research on interdisciplinary agricultural landscape use at the Károly Eszterházy University is to identify fruit varieties from the period of organic landscape use in the eastern part of the Eger wine region, i.e. the Bükkalja group of small landscapes, and to establish a nursery from the trees searched for and in parallel with this, to determine their role in folk and agricultural culture through ethnopomological research. The fruit trees found during fieldwork are mostly located on the borders of Eger and Noszvaj. As the fruit production and agricultural culture of Eger is very different from the organic landscape use in Bükkalja, and its economic and social character is also different, I focus on Noszvaj, which gives the most saved grafts.

Noszvaj is located in the Bükkalja settlement network, in the middle of a wide mountain foot surface, mostly belonging to the middle settlement belt extending onto the rhyolite tuff surface. (Baráz, 2014) This settlement is characterized by a landscape forming a transition between plains and mountains, where during the 18-19th century, livestock and arable farming competed with each other as the dominant form of farming. (Baráz, 2014) It is also important to point out that, although ancient viticulture and horticulture were of different importance from 
settlement to settlement, and having survived the period of Turkish rule, and having even developed in certain elements, it is still decisive to the present day. However, during the 18-19th century, vine monoculture developed mainly in the surroundings of Eger, and it gradually spread to Bükkalja as well.

\section{Results}

In the map entitled "Wine Map of Hungary by Wine Regions" published by the Royal Hungarian Ministry of Agriculture, Industry and Commerce in 1884, the western part of Bükkalja belonged to the Eger-Visonta wine region of the Tiszáninnen wine district (III.), forming its easternmost point. ${ }^{1}$ From an ethnopomological point of view, this is important because fruit was also grown in the ridges of the vineyards, which gained new impetus after the destruction of the grape caused by phylloxera in the late 19th century. Although the Fruit Society, which had already spread its scope to the area of Borosd County, was trying to boost fruit production in 1859, there were primarily only poor quality trees and a low level cultivation system until the middle of the 20th century. We do not know about contiguous orchards on the outskirts of the villages; fruit was grown mostly in the gardens and vineyards around the house.

Examining the data of the 1895 statistics on fruit trees, we find it striking that fruit production was of outstanding importance in Noszvaj among the settlements of the region. (Viga, 1985) In general, the undemanding plum varieties, which do not need regular care, were the most popular, followed by apple, sour cherry, then peach and finally cherry trees. This order did not change much by 1935, either, but the importance of intensive varieties slightly increased.

Comparing Bükkalja's excellent fruit-growing capacities and tree population, we can see a rather contradictory picture about the area's fruit culture and its place in the traditional culture. Fruit growing was carried out fundamentally in an extensive way, although all the conditions for intensive production were in place for developing intensive production methods. Gyula Viga sees the resolution of this contradiction in the absence of sales opportunities, as fruit buying-in was essentially unorganized in this area. (Viga, 1985. 292.)

It was only from the 1920s that the cherry-producing monoculture of Szomolya and Noszvaj was developed, primarily due to the market of Eger. On the whole, however, fruit production played a decisive role only in small-scale family farms, which, due to their scarce financial resources and lack of draft animals, were unable to take the fruit produced by them to distant markets. "That is, - because of the stagnant economic and social structure -, the population of the area could not take advantage of the capacity of the area and what would have brought prosperity to them.” (Viga, 1985. 282.) 
In the first half of the 19th century, Noszvaj, which was the subject of a closer investigation, was largely owned by the Almásy family; then István Steinhauser, resident of Eger, imperial purveyor and wholesaler bought the whole Almásy estate in 1869. Later he gave it as dowry to her daughter Berta, who married chief quartermaster Gyula Gallasy in 1878. (Pap, 2017.)

In 1895 the utilizable land area of the village was 3272 cadastral acres, of which 1272 acres were arable land, 88 acres were used as meadows, 493 acres as pasture, 961 acres as forest and only 43 acres were registered as vines. (Viga, 1985) The remaining 246 cadastral acres were registered as gardens and orchards, which is a very high number compared to similar figures in the surrounding settlements. (By comparison, in the neighbouring Szomolya and in Bogács, which is much larger in terms of population, the size of gardens and orchards was 95-95 cadastral acres.). However, at that time nearly 30,000 plum trees, which was an extremely high number, were registered in the statistics mentioned above. Two-thirds of the fruit trees of Novaj were plum trees, with cherries being in second place, with only 6574 trees. It is worth noting that in the farm statistics of 1935 only 7645 plum trees are included. The issue of the outstanding plum tree population of Noszvaj at the turn of the century is worth further research.

\section{Conclusions}

What role did fruits play in the everyday life of the people living in Novaj? It is typical of small-scale family farms that they were basically trying to meet their own consumption needs, so fruit is also supposed to have been an important part of the nutrition of the local people primarily. In addition to raw consumption, the most important processing method was making jam, which has preserved its popularity up to our own day. In the region, first of all, the Noszvaj plum jam was most widely available, which was also sold at the market of Eger and Mezőkövesd, but it was not uncommon that it was offered by market women in Miskolc, too. In addition to cooking jam, drying was another way of preserving; "home canning", which is very popular nowadays, was not known at that time. Fruits of inferior quality or which started to deteriorate, unsuitable for sale, landed in the mash, which was used to make brandy, and it was also popular because of its high price.

Fruit trading was only an additional part of the livelihoods of people living in Noszvaj, but it was still one of its significant bases. On the basis of the research carried out by Gyula Viga, we can distinguish two main lines of the fruit trade in Bükkalja. (Viga 1986.) One is trade within the boundaries of the group of small landscapes, a kind of local trade, while the other is trade between the much smaller 
landscapes crossing the borders of the region primarily towards the Great Plain. In the latter, the plums produced in large quantities were mostly exchanged by the product surpluses of the people living on the Great Plain, which were most often crops or one of the fodder plants. From the turn of the century, the transportation on the Great Plains was carried out by drivers of animal-drawn carts specialized for long distances, who were occasionally hired by 5-6 women. Local sales were also usually performed by women who carried the plums in carrying baskets made from hazel twigs locally, to the markets of Kövesd or Eger.

By the first decades of the 20th century, plums were gradually replaced by shortstemmed black cherries, which were more and more produced intensively. The reason for this was that in the 1930s even 2-3 wagons of them were bought by merchants of Pest, who delivered the high quality fruit to the German markets.

On the whole, it can be stated that fruit-growing played a very varied role in the folk culture of the settlements of Bükkalja, including Noszvaj. Fruit was one of the most important commodities in the trade between the Great Plain and the Highlands; nevertheless its production was based on extremely low quality cultivation. In spite of the fact that it was only a supplement to the livelihoods of the local population, it played an extremely important role. However, intensive horticulture was not developed in the area.

\section{Reference sources}

[1.] [1.] Frisnyák Sándor (1995): Magyarország történeti földrajza. [Historical Geography of Hungary]. Budapest 51-53.

[2.] [2.] Baráz Csaba (2014): Tájművelés és táji kapcsolatok a Bükkalján. [Landscape Cultivation and Landscape Relationships in Bükkalja]. Történeti Földrajzi Közlemények 2. évf. 1-2 sz. 111-112.

[3.] [3.] Viga Gyula (1985): Gyümölcstermesztés és gyümölccsel való kereskedelem a Bükkalján. [Fruit Production and Fruit Trading in Bükkalja]. A Herman Ottó Múzeum Évkönyve XXII-XXIII. (Annales Musei Miskolciensis de Herman Ottó Nominati) Miskolc 287.

[4.] [4.] Pap József (2017): Egerből Noszvajra : Térbeli és társadalmi mobilizáció Borsod és Heves határán. [From Eger to Noszvaj: Spatial and Social Mobilization on the Border of Borsod and Heves Counties]. Acta Academiae Agriensis. Nova Series tom. XLIV. Sectio Historiae. (Tanulmányok Gebei Sándor 70. születésnapjára. Szerk. Borbély Zoltán - Kristóf Ilona. Eger 489507. 
[5.] [5.] Viga Gyula (1986): Tevékenységi formák és a javak cseréje a Bükk-vidék népi kultúrájában. [Forms of Activities and Exchange of Goods in the Folk Culture of the Bükk Region]. Borsodi Kismonográfiák 23. Miskolc

[6.] [6.] "Wine Map of Hungary by Wine Regions" published by the Royal Hungarian Ministry of Agriculture, Industry and Commerce. Accessed on 20.12, 2019.

[7.] https://dspace.oszk.hu/handle/20.500.12346/50788

\section{Szerző}

Borbély Zoltán

PhD., adjunct

Eszterházy Károly University

Department of History

borbely.zoltan@uni-eszterhazy.hu 